\title{
EFEK PELATIHAN WASIT MELALUI VIRTUAL MEETING TERHADAP PENINGKATAN KOMPETENSI SDM WASIT SENAM TINGKAT PROVINSI TAHUN 2020
}

\author{
Mona Fiametta Febrianty ${ }^{1}$, Nina Sutresna ${ }^{2}$, Nida'ul Hidayah ${ }^{3}$ \\ ${ }^{1}$ Program Studi Kepelatihan Fisik Olahraga, Universitas Pendidikan Indonesia, \\ Indonesia \\ ${ }^{2}$ Program Studi Pendidikan Kepelatihan Olahraga, Universitas Pendidikan Indonesia, \\ Indonesia \\ e-mail: monafiametta@upi.edu,nina.sutresna@upi.edu,nidaul@upi.edu
}

\begin{abstract}
Abstrak
Peran seorang wasit pada cabang olahraga tidak terukur dalam hal ini adalah Senam memiliki posisi yang amat sentral. Kualifikasi wasit senam turut mempengaruhi keberhasilan atlet dalam meraih prestasi. Sehingga penyebaran SDM wasit yang berkualitas sangatlah diharapkan tersebar secara merata. Untuk mewujudkan pemerataan SDM perlu dilakukan pelatihan terhadap para wasit yang merupakan perwakilan dari tiap kota atau kabupaten. Pada masa pandemik Covid-19 ini tidaklah memungkinkan untuk melakukan pelatihan secara tatap muka langsung, oleh sebab itu alternative yang dapat dilakukan adalah dengan virtual meeting. Tujuan penelitian ini adalah untuk mengetahui efek dari pelatihan secara virtual terhadap peningkatan kompetensi wasit senam. Metode penelitian yang digunakan yaitu pre eksperimental design. Populasi penelitian ini adalah wasit senam tingkat provinsi dengan sample sebanyak 30 orang. Instrumen yang digunakan adalah butir soal mengenai perwasitan berjumlah 40 soal. Hasil penelitian ini menunjukkan bahwa terdapat peningkatan kompetensi SDM wasit yang signifikan melalui pelatihan wasit secara virtual meeting.
\end{abstract}

Kata-kata kunci: Kompetensi Wasit Senam, Pelatihan Wasit

\begin{abstract}
The role of a referee on sports is not measurable, in this case, gymnastics has a very central position. Qualifications of gymnastics referees also influence the success of athletes in achieving their achievements. So, the distribution of the human resources of the referee who qualified is expected to spread evenly. To create equitable referee human resources, it is necessary to do training on the referees who are representatives of each city or district. At this pandemic of Covid-19, it is not possible to conduct training face-to-eye, therefore the alternative that can be done is a virtual meeting. The purpose of this research is to know the effect of virtual training on improving the competence of gymnastics referees. The research methods used are pre-experimental design. The population of this research is a province-level gymnastic referee with 30 people as samples. The instrument used is a matter of 40 questions about refereeing. The results showed that there was a significant increase in referee human resources competency through a virtual meeting refereed training.
\end{abstract}

Keywords : Gymnastics Referee Competence, Referee Training 


\section{PENDAHULUAN}

Dalam mewujudkan prestasi olahraga yang membanggakan, membangun watak bangsa untuk mengangkat harkat dan martabat bangsa Indonesia, berbagai lembaga terkait seperti FPOK, Disorda dan organisasi olahraga di bawah naungan KONI seperti Pengda PERSANI memiliki peran yang sangat strategis dalam kerangka program pembinaan olahraga. Beberapa isu permasalahan yang mengemuka antara lain; kualitas dan kuantitas SDM (atlet, pelatih dan wasit), kredibilitas managerial SDM dan cabang olahraga, kesejahteraan atlet, pelatih, wasit dan mantan atlet, lemahnya menerapan iptek latihan dan pertandingan, belum adanya standar kualitas,serta masih lemahnya sistem pembinaan dalam bidang perwasitan. Padahal salah satu tujuan umum pembinaan prestasi yang sangat strategis adalah; Tergalang dan terbina atlet potensial dengan para pelatih dan wasit handal yang berpotensi serta tersedia unsur-unsur pendukungnya yang representatif. Begitu pula hubungan komunikasi antar pimpinan juga berjalan sangat baik sehingga mempengaruhi tekad meraih targettarget medali emas. Dukungan terhadap Binpres dan Litbang seperti penataran wasit yang tengah berlangsung sangat mempengaruhi pencapaian hasil. (Arifin, 2017)

Kedudukan wasit dalam kompetisi olahraga, khususnya cabang tidak terukur memiliki posisi yang amat sentral. Tugas dan fungsi wasit dalam olahraga tidak terukur memiliki peran yang sangat dominan dalam menentukan seorang juara. Mengingat tugas wasit yang cukup dominan dalam olahraga penilaian ini, maka wasit harus memiliki perilaku yang baik dan dibekali jiwa fair play di luar dan di dalam lapangan. Wasit juga seringkali dijadikan sasaran ketidakpuasan pesenam, official, dan bahkan penonton. Hal ini terjadi sebagai akibat rasa tidak puas atas hasil yang diperoleh pesenam yang salah satunya disebabkan oleh kinerja wasit. Peranan wasit dalam hal ini adalah memberikan skor nilai terhadap seorang pesenam yang baru menyelesaikan penampilannya. Dalam melakukan hal itu, seorang wasit harus mempertimbangkan: (1) Memberi kelebihan paa penampilan yang terbaik (2) Memastikan bahwa skor yang diberikan dapat membedakan antara penampilan pesenan yang baik dan pesenan yang kurang baik. (Mahendra, 2012).

Kualifikasi wasit senam turut mempengaruhi keberhasilan atlet dalam meraih prestasi. Oleh sebab itu dibutuhkan dukungan SDM wasit dalam meningkatkan prestasi cabang olahraga senam. Permasalahan pada saat ini adalah minimnya jumlah wasit serta penyebaran SDM yang berkualitas tidak merata ke seluruh daerah. Salahsatau penyebab kelemahan ini adalah sebagai dampak dari pembinaan SDM wasit dan pelatih yang belum terarah, belum diolah sesuai kompetensinya, pembinaan yang tidak berkelanjutan, dll yang dipengaruhi oleh lingkungan global, regional dan nasional. (Ma'mun, 2008)

Untuk mewujudkan pemerataan SDM wasit senam terutama dalam memahami peraturan/ COP (code of point), perlu dilakukan pendampingan dan pembinaan yang periodik. Pembinaan dalam penelitian ini adalah pelatihan yang bersifat virtual atau dapat juga disebut dengan e-learning. Hal ini dimaksudkan karena pada saat sekarang dengan merebaknya virus Covid-19, tidak memungkinkan untuk melakukan pertemuan secara tatap muka dalam pelatihan. Kursus online atau belajar online adalah serangkaian 
pengalaman instruksional dengan menggunakan jaringan digital untuk berinteraksi, belajar dan berdiskusi. Kursus online tidak memerlukan pertemuan tatap muka di lokasi fisik (Studiilmu, 2020). Sistem pembelajaran atau pelatihan secara virtual ini merupakan konsekuensi logis dari perkembangan teknologi yang dapat kita gunakan selama masa pandemi Covid-19 ini. Sejalan dengan pendapat (Permatasari \& Hardiyan, 2018) bahwa e-learning merupakan dasar dari konsekuensi logis dari perkembangan teknologi informasi dan komunikasi. Pendapat lain menjelaskan online learning merupakan metode pembelajaran dengan memanfaatkan teknologi, internet, atau intranet, dengan kekuatan yang tidak terkendala waktu dan lokasi, metode pengajaran kreatif, dan lebih bersifat trainee-centered (Darmayanti, 2019) Sehingga dengan cara inilah kita dapat melaksanakan pelatihan tanpa harus bertatap muka langsung guna menghindari penyebaran Covid-19.

Tujuan dari penelitian ini adalah untuk mengetahui efek dari pelatihan wasit secara virtual terhadap peningkatan kompetensi wasit senam.

\section{METODE}

Metode penelitian yang digunakan adalah pre eksperimental design dengan jenis pre test and post test one group design. Waktu pengambilan data dilakukan pada bulan Juli 2020. Alur penelitian dilakukan secara tersusun dengan cara mengidentifikasi masalah, memilih populasi dan sampling, pengambilan data, analisis data dan pelaporan hasil penelitian.
Teknik pengumpulan data yang dilakukan adalah menggunakan alat tes. Sedangkan alat tes yang digunakan berupa butir soal mengenai kompetensi wasit senam sebanyak 40 buah.

Populasi dalam penelitian ini ada wasit senam yang tersebar di seluruh Indonesia dengan jumlah 30 orang. Sedangkan sample yang digunakan adalah keseluruhan dari jumlah populasi yang berjumlah 30 orang yang terdiri dari 13 wasit senam ritmik, 9 wasit senam artistik putra dan 8 wasit enam artistik putri.

Tahapan penelitian yang dilakukan oleh peneliti adalah sebagai berikut: (1) Membuat program pelatihan wasit senam (2) Menentukan populasi dan sampel (3) Melakukan tes awal (4) Memberikan treatment berupa pelatihan (5) Melakukan tes akhir (6) Melakukan pengolahan dan analisis data (7) Dilakukan pembahasan hasil dari analisis dan olahdata (8) Menyimpulkan hasil penelitian.

Teknik analisis data yang digunakan adalah analisis deskriptif dan pengolahan data menggunakan SPSS versi 23, dengan mencari uji normalitas dan uji hipotesis. Uji normalitas menggunakan Kolmogorov-Smirnov Test sedangkan uji hipotesis menggunakan Paired Sample Test.

\section{HASIL DAN PEMBAHASAN HASIL}

Hasil penelitian efek pelatihan wasit melalui virtual meeting terhadap peningkatan kompetensi SDM wasit senam dapat dilihat pada Tabel 1 (Efek pelatihan wasit terhadap peningkatan kompetensi SDM wasit senam) dan Grafik 1 (Persentase peningkatan kemapuan kompetensi SDM wasit senam). 
Tabel 1. Efek Pelatihan Wasit Terhadap Kompetensi SDM Wasit Senam

\begin{tabular}{|c|c|c|c|c|c|c|c|}
\hline & \multicolumn{5}{|c|}{ Paired Differences } & \multirow{3}{*}{$\mathrm{t}$} & \multirow{3}{*}{$\begin{array}{l}\text { Sig. } \\
(2- \\
\text { tailed })\end{array}$} \\
\hline & \multirow[t]{2}{*}{ Mean } & \multirow[t]{2}{*}{ Std } & \multirow[t]{2}{*}{$\begin{array}{l}\text { Std. } \\
\text { Error } \\
\text { Mean }\end{array}$} & \multicolumn{2}{|c|}{$\begin{array}{l}\text { 95\% Confidence } \\
\text { Interval of the } \\
\text { Difference }\end{array}$} & & \\
\hline & & & & Lower & Upper & & \\
\hline $\begin{array}{c}\text { Pair 1 } \\
\text { (Ritmik) }\end{array}$ & $-117,31$ & 76,64 & 21,26 & $-163,62$ & $-71,00$ & $-5,52$ & 0,000 \\
\hline $\begin{array}{c}\text { Pair } 2 \\
\text { (Art Pa) }\end{array}$ & $-244,44$ & 89,95 & 29,98 & $-313,58$ & $-175,31$ & $-8,15$ & 0,000 \\
\hline $\begin{array}{c}\text { Pair } 3 \\
\text { (Art Pi) }\end{array}$ & $-246,88$ & 121,33 & 42,90 & $-348,31$ & $-145,44$ & $-5,76$ & 0,001 \\
\hline
\end{tabular}

Tabel 1 menjelaskan sebagai berikut. Nilai Sig untuk Ritmik sebesar $0.000<0.05$, maka dapat disimpulkan bahwa terdapat pengaruh yang signifikan pelatihan wasit melalui virtual meeting terhadap peningkatan kompetensi SDM wasit senam ritmik. Nilai Sig untuk Artistik Putra sebesar $0.000<0.05$, maka dapat disimpulkan bahwa terdapat pengaruh yang signifikan pelatihan wasit melalui virtual meeting terhadap peningkatan kompetensi SDM wasit senam artistik putra. Nilai Sig untuk Artistik Putra sebesar $0.001<0.05$, maka dapat disimpulkan bahwa terdapat pengaruh yang signifikan pelatihan wasit melalui virtual meeting terhadap peningkatan kompetensi SDM wasit senam artistik putri.

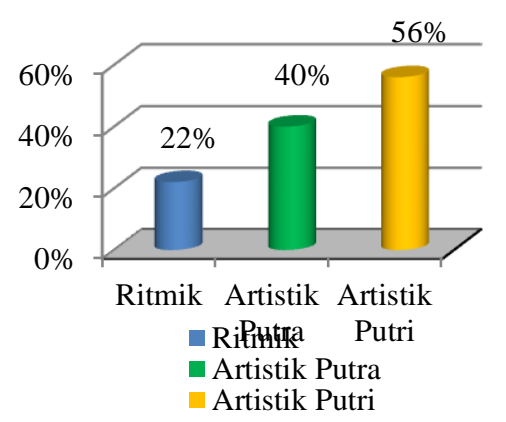

Grafik 1. Persentase Peningkatan Kemampuan Kompetensi SDM Wasit Senam
Grafik 1 menjelaskan bahwa terdapat peningkatan kemampuan kompetensi SDM wasit senam ritmik sebesar 22\%, terdapat peningkatan kemampuan kompetensi SDM wasit senam artistic putra sebesar $40 \%$ dan terdapat peningkatan kemampuan kompetensi SDM wasit senam artistic putri sebesar $56 \%$.

\section{PEMBAHASAN}

Secara kesuluhan berdasarkan hasil olah data maka dapat dilihat bahwa pelatihan wasit melalui virtual meeting memberikan efek atau pengaruh yang signifikan terhadap peningkatan kompetensi SDM wasit senam, baik wasit senam ritmik, artistik putra maupun artistik putri.

Senam merupakan salah satu olahraga penilaian. Kedudukan wasit cukup dominan karena dia memiliki otoritas menilai dan memutuskan kalah atau menang dalam perlombaan. Dalam COP (Code Of Points) panel wasit untuk setiap nomor maksimal satu wasit untuk tiap negara/daerah (Gymnastique, 2013). Munculnya peraturan tersebut sebagai upaya untuk meminimalisir tingkat subjektifitas dalam olahraga ini.

Sistem kualifikasi juri bertujuan untuk menghasilkan kondisi yang kondusif bagi peningkatan kemampuan 
juri senam Indonesia. Melalui sistem kualifikasi ini, perekrutan juri dapat dilakukan melalui sub-sistem pendidikan perwasitan yang sistematis dan teratur. Kriteria untuk menentukan kualifikasi seorang wasit menurut FIG adalah sebagai berikut: (1) Memastikan terkuasainya pengertian yang mendasar tentang perwasitan untuk tingkat pemula, terutama dalam penilaian rangkaian wajib (2) Memastikan terkuasainya pengertian yang mendasar tentang peraturan senam Internasional (FIG Code of Points) (3) Memastikan bahwa para juri senam memiliki pengalaman praktek mewasiti yang memadai di samping pengetahuan teoritisnya (4) Memastikan terciptanya standardisasi isi dan volume kursus/pendidikan perwasitan senam di seluruh Indonesia (5) Memastikan bahwa periode waktu yang dibutuhkan untuk kursus perwasitan memang mendukung terhadap penguasaan pengetahuan perwasitan yang menyeluruh (6) Memastikan bahwa setiap peringkat wasit di seluruh Indonesia mendapat kesempatan dan penghargaan yang memadai dalam upaya peningkatan peringkatnya, disesuaikan dengan tingkat kejuaraan dan peringkat pesenam yang diwasitinya. (Sugihartono, 2020)

Tahapan sistem kualifikasi wasit senam menurut FIG (Federation Internatiole Gymanstics) General Judges' Rules pengelompokkan kategori wasit dalam cabang olahraga senam terdiri dari 4 katagori (Gymnastique, 2020). Katagori 4 harus memiliki pengalaman dalam mewasiti pada kejuaraan tingkat internasional dan memiliki brevet nasional dan internasional yang telah ditentukan oleh FIG. Untuk katagori 3, harus memiliki pengalaman mewasiti pada kejuaraan tingkat provinsi/nasional sebagai wasit Difficulty atau execution. Dan untuk katagori 2 harus memiliki pengalaman mewasiti pada kejuaraan tingkat kotamadya/provinsi sebagai wasit Difficulty atau execution. Sedangkan untuk katagori I, seorang juri harus memiliki pengalaman mewasiti pada tingkat antar klub atau berpengalaman mewasiti sebagai wasit execution. Implementasi aturan ini jga diterapkan pada level nasional, dimana katagori untuk menunjukan otoritas wasit terbagi menjadi 4 katagori, yaitu katagori 1 berhak untuk mewasiti kejuaraan pada level nasional seperti PON, POPNAS, dll. Sedangkan untuk katagori 2 mereka memiliki kewenangan untuk menjadi wasit pada level provinsi (PPORDA, POPDA), katagori 3 untuk perlombaan tingkat kabupaten/ kota, sedangkan katagori 3 adalah sebagai prasyarat minimal untuk dapat mengikuti ujian wasit baik pada level provinsi, namun belum memiliki hak untuk menjadi wasit.

Untuk tercapaianya kualifikasi SDM wasit sesuai aturan FIG secara merata, maka diadakanlah suatu pelatihan yang ditujukan untuk meningkatkan kompetensi wasit tersebut. Pelatihan menurut Chusway dalam (Elfrianto, 2016) adalah proses mengajarkan keahlian dan memberikan pengetahuan yang perlu, serta sikap supaya mereka dapat melaksanakan tanggung jawabnya dengan standar. Sedangkan Mathis dalam (Richardo, 2015) menyatakan bahwa pelatihan merupakan suatu proses dimana orangorang mencapai kemampuan tertentu untuk mencapai tujuan organisasi. Pelatihan didefinisikan pula oleh Dessler dalam (Elfrianto, 2016) sebagai proses dimana orang-orang mencapai kemampuan tertentu untuk membantu mencapai tujuan organisasi. Pelatihan lebih cenderung berorientasi jangka pendek, pelatihan berpengaruh pada kinerja dan jika pelatihan yang 
dilakukan oleh perusahaan berhasil maka kinerja karyawan akan meningkat dengan sendirinya. Tujuan dari pelatihan tersebut adalah untuk meningkatkan kualitas sumber daya manusia dalam menunjang pelaksanaan tugas yang menjadi tanggung jawabnya. Hal ini sejalan dengan pendapat Jayanthi (Jayanthi \& Cahyana, 2017) yaitu program pelatihan bertujuan untuk meningkatkan dan mengembangkan keterampilan, keahlian, kecakapan serta kemampuan seorang karyawan, sehingga perusahaan memiliki karyawan yang terampil, cakap, mempunyai prestasi kerja yang tinggi serta tanggung jawab yang besar terhadap perusahaan. Selain itu secara umum tujuan dari kegiatan pelatihan dan pengembangan adalah untuk menyediakan sumber daya manusia yang siap dan mampu untuk ditugaskan baik dari sisi kompetensi, mananjerial, maupun berperilaku sehingga mereka dapat memberikan kontribusi yang positif bagi kebutuhan organisasi ataupun perusahaan secara terus menerus sesuai dengan perkembangan persaingan dan jabatan (Khurotin \& Afrianty, 2018).

Betapa pentingnya diadakan pelatihan ini sehingga pada saat pandemi pun tidak membuat kegiatan pelatihan tertunda. Maka pelatihan bersifat virtual adalah solusinya. Pelatihan secara virtual merupakan suatu pelatihan berbasis TIK. Kegiatan pelatihan dilakukan secara elektronik atau biasa disebut dengan e-learning. Henderson dalam (Khurotin \& Afrianty, 2018) mendefinisikan e-learning sebagai berikut: (1) e-learning belajar pada jarak yang menggunakan teknologi komputer (biasanya Internet) (2) $e$ learning memungkinkan karyawan untuk belajar komputer kerja mereka tanpa bepergian ke kelas (3) e-learning dapat menjadi dijadwalkan sesi dengan instruktur dan siswa lain, atau dapat sesuai permintaan karyawan saja yang dapat mengambil untuk belajar secara mandiri pada saat itu lebih mudah.

Pada dasarnya cara penyampaian atau cara pemberian (delivery system) dari e-Learning, dapat digolongkan menjadi dua, yaitu: (1) One way communication (komunikasi satu arah); dan (2) Two way communication (komunikasi dua arah). Komunikasi atau interaksi antara guru dan murid memang sebaiknya melalui sistem dua arah. Dalam e-learning, sistem dua arah ini juga bisa diklasifikasikan menjadi dua, yaitu: 1. Dilaksanakan melalui cara langsung (synchronous). Artinya pada saat instruktur memberikan pelajaran, murid dapat langsung mendengarkan; dan 2. Dilaksanakan melalaui cara tidak langsung (a-synchronous). Misalnya pesan dari instruktur direkam dahulu sebelum digunakan (Hamonangan, 2012). Karakteristik online learning juga diungkapkan oleh Hardjito dalam (Waryanto, 2006) sebagai berikut: (1) Sebagai media interpersonal dan suga sebagai media massa yang memungkinkan terjadinya komunikasi one-to-one maupun one-to-many (2) Memiliki sifat interaktif

Memungkinkan terjadinya komunikasi secara sinkron (synchronous) maupun kmunikasi tertunda (asyncronus), sehingga memungkinkan terselenggarakannya ketiga jenis komunikasi yang merupakan syarat terselenggarakannya suatu proses pembelajaran. Dari beberapa penjelasan tersebut maka dapat disimpulkan bahwa pelatihan secara virtual ini tergolong kepada e-learning/online training. Di era digital ini pemanfaatan e-learning diharapkan dapat lebih membantu pelatihan atau pembelajaran tanpa harus bertatap muka secara langsung. Sehingga kegiatan pelatihan atau pembelajaran dapat dilakukan dimana 
saja. Keuntungan dari penggunaan $e$ learning yaitu (1) Merupakan media komunikasi yang efektif, cepat dan kredibel untuk menyampaikan materi elearning dari seorang pakarnya (2) Mencakup area yang luas (3) Peserta memperoleh visualisasi lengkap pembicarannya (4) Kelas Besar atau kecil : Kelas tidak membutuhkan bentuk fisik lagi, semuanya dapat dibangun dalam aplikasi Internet (5) Kapan saja, dimana saja : Dapat diakses dari lokasi mana saja dan bersifat global. Elearning menghilangkan batasan waktu dan tempat dengan karakteristik kelas tradisonal dengan menggunakan mode komunikasi asynchronous seperti email, diskusi online, mahasiswa dapat mengakses 24 jam setiap hari (6) Membangun Komunitas : Pembelajaran adalah proses sosial. Siswa dapat belajar saling tukar informasi satu dengan yang lain seperti dengan instruktur. Dapat diciptakan interaksi yang bersifat real time maupun non-real time (7) Peningkatan Pembelajaran siswa : Melalui Internet organisasi akan dapat lebih fokus pada penyelenggaraan program pendidikan/pelatihan. Mengakomodasi keseluruhan proses belajar dan juga transaksi. Materi dapat dirancang secara multimedia dan dinamis. Peserta belajar dapat terhubung ke berbagai perpustakaan maya di seluruh dunia dan menjadikannya sebagai media penelitian dalam meningkatkan pemahaman pada bahan ajar. Guru/instruktur/dosen dapat secara cepat menambahkan referensi bahan ajar yang bersifat studi kasus, trend industri dan proyeksi teknologi ke depan melalui berbagai sumber untuk menambah wawasan peserta terhadap bahan ajarnya. Sedangkan untuk keuntungan dari penggunaan blended learning sebagai sebuah kombinasi pengajaran langsung (face-to-face) dan pengajaran online, tapi lebih daripada itu sebagai elemen dari interaksi sosial yaitu: (a) Adanya interaksi antara pengajar dan mahasiswa (b) Pengajaran pun bisa secara on line ataupun tatap muka langsung (b) Blended Learning = combining instructional modalities (or delivery media) (c) Blended Learning = combining instructional methods.

Lebih lanjut Elangoan dalam (Elyas, 2018) menjelaskan mengenai keunggulan e-learning yaitu Pertama, Tersedianya fasilitas e-moderating di mana dosen dan mahasiswa dapat berkomunikasi secara mudah melalui fasilitas internet secara regular atau kapan saja kegiatan berkomunikasi itu dilakukan dengan tanpa dibatasi oleh jarak, tempat dan waktu. Kedua, Dosen dan mahasiswa dapat menggunakan bahan ajar atau petunjuk belajar yang terstruktur dan terjadual melalui internet, sehingga keduanya bisa saling menilai sampai berapa jauh bahan ajar dipelajari. Ketiga, Mahasiswa dapat belajar atau me-review bahan ajar (mata kuliaha) setiap saat dan di mana saja kalau diperlukan mengingat bahan ajar tersimpan di komputer. Keempat, Bila mahasiswa memerlukan tambahan informasi yang berkaitan dengan bahan yang dipelajarinya, ia dapat melakukan akses di internet secara lebih mudah. Kelima, Baik doen maupun mahasiswa dapat melakukan diskusi melalui internet yang dapat diikuti dengan jumlah peserta yang banyak, sehingga menambah ilmu pengetahuan dan wawasan yang lebih luas. Keenam, Berubahnya peran mahasiswa dari yang biasanya pasif menjadi aktif. Ketujuh, Relatif lebih efisien. Selain itu (Mashud, James Tangkudung, 2018) menambahkan bahwa intervensi pembelajaran ataupun pelatihan menggunakan online learning menjadikan pembelajaran atau pelatihan lebih fleksibel. Artinya peserta atau 
pebelajar bisa belajar diamana saja, kapan saja, dan dengan siapa saja menggunakan bahan yang disiapkan dan disimpan secara online.

Disamping kelebihan tentunya ada juga berbagai kekurangan dalam kegiatan e-learning ini yang dijelaskan oleh Bullen dalam (Yustanti \& Novita, 2019) yaitu Pertama, Kurangnya interaksi antara guru dan siswa atau bahkan antar siswa itu sendiri. Kurangnya interaksi ini bisa memperlambat terbentuknya values dalam proses belajar dan mengajar. Kedua, Kecenderungan mengabaikan aspek akademik atau aspek sosial dan sebaliknya mendorong tumbuhnya aspek bisnis/komersial. Ketiga, Proses belajar dan mengajarnya cenderung ke arah pelatihan daripada pendidikan. Keempat, Berubahnya peran guru dari yang semula menguasai teknik pembelajaran konvensional, kini juga dituntut mengetahui teknik pembelajaran yang menggunakan ICT. Kelima, Siswa yang tidak mempunyai motivasi belajar yang tinggi cenderung gagal. Keenam, Tidak semua tempat tersedia fasilitas internet. Ketujuh, Kurangnya tenaga yang mengetahui dan memiliki ketrampilan internet. Kedelapan, Kurangnya penguasaan bahasa komputer.

Berbagai kelebihan dari e-learning tersebut menguatkan hasil penelitian yang peneliti lakukan. Yaitu terdapat pengaruh yang signifikan dari pelatihan secara virtual meeting terhadap peningkatan kompetensi SDM wasit senam. Beberapa penelitian sebelumnya menjelaskan hal serupa mengenai pengaruh penggunaan e-learning atau pembelajaran berbasis TIK. Penelitian tersebut menjelaskan bahwa implementasi e-learning cukup efektif digunakan untuk meningkatkan pemahaman peserta terhadap mata pelatihan (Rahman, Amarullah, \&
Hidayah, 2020). Selanjutnya pembelajaran e-learning sebagai media pembelajaran di SMK Telkom Sandhy Putra Purwokerto cukup efektif (Hanum, 2013). Penelitian yang lain mengatakan bahwa e-learning di BCA KCU Tangerang mempunyai pengaruh yang cukup baik dan berarah positif terhadap kinerja karyawan BCA KCU Tangerang (Permatasari \& Hardiyan, 2018)

\section{SIMPULAN DAN SARAN}

Berdasarkan hasil pengolahan data dan pembahasan, maka peneliti dapat menyimpulkan bahwa pelatihan wasit secara virtual meeting memberikan pengaruh yang signifikan terhadap peningkatan kemampuan kompetensi SDM wasit senam.

Saran penulis agar kegiatan pelatihan ini dapat dilanjutkan secara bertahap dan berjenjang. Pelatihan ini diharapkan dapat memacu KONI dan PERSANI untuk mengadakan pelatihan perwasitan yang lebih luas dan teroganisir dengan baik.

\section{DAFTAR PUSTAKA}

Arifin, D. (2017). Persani Selenggarakan Penataran Wasit Senam Artistik Putral Putri. Jakarta: bisniswisata.co.id.

Darmayanti. (2019). Jenis-jenis Metode Pelatihan yang Interaktif. Jakarta: Balai Pendidikan dan Pelatihan Aparatur.

Elfrianto. (2016). Manajemen Pelatihan Sumber Daya Manusia Dalam Meningkatkan Mutu Lulusan. Jurnal EduTech, 2(2), 46-58.

Elyas, A. H. (2018). Penggunaan Model Pembelajaran E-Learning Dalam Meningkatkan Kualitas Pembelajaran. Jurnal Warta, 56(04), 1-11. 
Gymnastique (p. 20). (2013).

Gymnastique, R. I. D. E. (2020). FÉDÉRATION

INTERNATIONALE

$D E$

GYMNASTIQUE FIG General

Judges 'Rules Cycle 2017-2020.

Hamonangan, T. (2012). Model Pembelajaran Berbasis E-Learning Suatu Tawaran Pembelajaran Masa Kini dan Masa Yang Akan Datang. Pengantar Teknologi Informasi, 124.

Hanum, N. S. (2013). Keefetifan elearning sebagai media pembelajaran (studi evaluasi model pembelajaran e-learning SMK Telkom Sandhy Putra Purwokerto). Jurnal Pendidikan Vokasi, 3(1), 90-102.

https://doi.org/10.21831/jpv.v3i1.1 584

Jayanthi, Y., \& Cahyana, A. (2017). Pengaruh Hasil Pelatihan Terhadap Kinerja Karyawan Di Balai Pelatihan Manajerial Pt. Kai Bandung. Jurnal Pendidikan Luar Sekolah, 10(2).

Khurotin, N., \& Afrianty, T. W. (2018). Analisis pelatihan dan Pengembangan Sumber Daya Manusia di PT Beon Intermedia Cabang Malang. Jurnal Administrasi Bisnis, 64(1), 195203.

Ma'mun, A. (2008). Pembangunan Olahraga Masyarakat di Jawa Barat. FPOK UPI \& Pemda Prov. Jawa Barat.

Mahendra, A. (2012). Materi Pendidikan Wasit Senam Artistik Putra. 3.

Mashud, James Tangkudung, W. (2018). Swimming Lesson Based on Interactive Multimedia. International Journal of Sports
Science, $\quad 8(3), \quad 91-96$. https://doi.org/10.5923/j.sports.201 80803.04

Permatasari, I., \& Hardiyan, H. (2018). Pengaruh E-Learning Sebagai Media Pelatihan dan Pengembangan Terhadap Kinerja Karyawan BCA KCU Tangerang. Jurnal Sisfokom (Sistem Informasi Dan Komputer), 7(1), 1. https://doi.org/10.32736/sisfokom. v7i1.275

Rahman, M. A., Amarullah, R., \& Hidayah, K. (2020). Evaluasi Penerapan Model Pembelajaran ELearning pada Pelatihan Dasar Calon Pegawai Negeri Sipil. Jurnal Borneo Administrator, 16(1), 101116. https://doi.org/10.24258/jba.v16i1. 656

Richardo, J. (2015). Pengaruh Pelatihan Kerja Dan Motivasi Terhadap Kinerja Karyawan Pt. Prudential Cabang Mrt Stars. Agora, 3(2).

Studiilmu. (2020). Pengertian Kursus Online atau Belajar Online.

Sugihartono, T. (2020). CODE OF POINT DAN RUBRIK PENILAIAN SENAM DALAM CODE OF POINT AND RUBRIC EVALUATION OF GYM IN. Jurnal Ilmiah Pengembangan Dan Penerapan IPTEKS, 18(1), 1-11.

Waryanto, N. H. (2006). Online Learning Sebagai Salah Satu Inovasi Pembelajaran. Pythagoras, 2(1), 10-23.

Yustanti, I., \& Novita, D. (2019). Pemanfaatan E-Learning Bagi Para Pendidik Di Era Digital 4 . 0. Prosiding Seminar Nasional, 338346. 